\title{
Retained Textile Foreign Bodies: Experience of 27 Years
}

\author{
Corpos Estranhos Têxteis Retidos: Experiência de 27 Anos
}

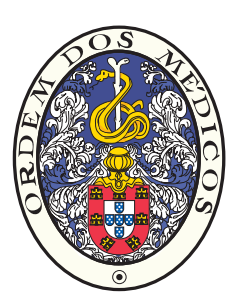

\author{
Soykan ARIKAN ${ }^{1}$, Ahmet KOCAKUSAK $\square^{2}$ \\ Acta Med Port 2015 Jul-Aug;28(4):494-500
}

\section{ABSTRACT}

Introduction and Aim: Retained intracorporeal textile products (gossypiboma-textiloma) are undesired and accidental surgical results for both patients and surgeons, which are underreported because of medicolegal remifications. Fourteen textiloma cases, who had been treated or whose treatment procedures had been followed-up personally by two general surgeons in a period of 27 years almost during their whole professional lives were presented to describe and define the clinical and pathological characteristics.

Material and Methods: Patient characteristics including gender and age, areas of location within the body, time intervals until diagnosis, clinical presentations and complaints, treatment modalities, complications, causative surgical interventions, and diagnostic approaches were retrospectively evaluated.

Results: Nine female and five male patients with a mean age of $43.07 \pm 15.23$ (median: 45) years at diagnosis were enrolled in the study. Cesarean section in three, inguinal hernioraphy in four, explorative laparotomy because of acute abdomen in one, sigmoid colon resection in one, appendectomy and right salpingoophorectomy in one, etrangulated incisional hernia after a previous surgical intervention because of an ovarian mass in one, thyroidectomy in one, epigastric hernioraphy in one, and bilateral segmental mastectomy with bilateral axillary sentinal lymph node dissection in one were the causative surgical interventions. Locations of textilomas were the abdominal cavity in seven, inguinal surgical wound in four, epigastric surgical wound in one, thyroidectomy lodge in one, and bilateral axillary cavities in one patient. The mean time interval until diagnosis was 14.48 (median: 5.5) months.

Discussıon: Earlier recognition of foreign bodies can provide a better outcome.

Conclusion: Gossypibomas are preventable iatrogenic faults which create severe problems. Strict adherence to the rules of the operation room is a must to keep the tip of the iceberg shut in the Pandora's box.

Keywords: Granuloma, Foreign-Body; Foreign Bodies.

\section{RESUMO}

Introdução e Objetivos: A retenção de materiais têxteis após a cirurgia é uma situação indesejada, tanto para o doente como para o cirurgião. Frequentemente são subnotificados por questões de natureza médico-legal. Apresentamos 14 casos de textilomas (compressoma) que foram tratados ou seguidos pessoalmente por dois cirurgiões gerais num período de 27 anos para descrever e definir as características clínicas e patológicas.

Material e Métodos: Foram avaliados retrospectivamente os dados relativos a uma serie de casos, nomeadamente: características dos doentes (sexo e idade), localização anatómica do corpo estranho, intervalo de tempo até ao diagnóstico, apresentação clínica, queixas, abordagem diagnóstica, motivo de cirurgia, tipo de tratamento cirúrgico e complicações.

Resultados: Foram identificados nove doentes do sexo feminino e cinco do sexo masculino, com uma média de idades de $43,07 \pm$ 15,23 (mediano: 45) anos para o momento do diagnóstico. Em três doentes a cirurgia prévia foi cesariana, em quatro casos herniorrafia inguinal, um doente submetido a laparotomia exploradora por abdome agudo, um doente no qual foi realizado uma sigmoidectomia, uma doente submetida a apendicectomia e salpingooforectomia direita, uma doente na qual a cirurgia anterior tinha sido para corrigir uma hérnia incisional após laparotomia por neoplasia do ovário, um caso de tiroidectomia total, uma herniorrafia por hérnia epigástrica e uma doente submetida cirurgia conservadora bilateral da mama com pesquisa de gânglio sentinela. A localização mais frequente dos compressomas foi intra-abdominal em sete casos, em quatro doentes a localização foi inguinal, um caso localizado na incisão da correcção da hérnia epigástrica, um doente com textiloma na loca de tiroidectomia, e no caso da doente submetida a cirurgia conservadora da mama em ambas regiões axilares se encontraram corpos estranhos/compressomas. O intervalo de tempo foi em média 14,48 (mediano: 5,5 ) meses.

Dıscussão: A identificação precoce de corpos estranhos pode assegurar um desfecho mais positivo.

Conclusão: Os compressomas são uma forma de iatrogenia evitável com consequências graves. O cumprimento rigoroso das normas no bloco operatório é essencial para manter a ponta do iceberg fechado na caixa de Pandora.

Palavras-chave: Corpos Estranhos; Granuloma de Corpo Estranho.

\section{INTRODUCTION}

Retained intracorporeal textile products are iatrogenic oversights. Although rarely encountered, they are undesired conditions which many surgeons may experience throughout in their professional lives. Beside causing many health problems for patients, they can also

bring about many clinical and legal affairs for surgeons. Most of them are being parried without any report because of medicolegal remifications. ${ }^{1,2}$ Underreporting mostly leads to publications as case reports only in the related literature. The reported cases are the tip of an iceberg only. ${ }^{3}$

\footnotetext{
1. General Surgery Clinic. Istanbul Education and Research Hospital. Istanbul. Turkey.

2. General Surgery Clinic. Haseki Education and Research Hospital. Istanbul. Turkey.

$\bowtie$ Autor correspondente: Ahmet Kocakusak. ahmetkocakusak@yahoo.com

Recebido: 11 de Novembro de 2014 - Aceite: 25 de Fevereiro de 2015 | Copyright @ Ordem dos Médicos 2015
} 
These foreign bodies are named as gossypiboma, textiloma, gauzoma or cottonoid inspired by gossypium which is the Latin synonym for cotton used in their production. ${ }^{3,4}$ This nomenclature could also have been derived to minimize the unsympathetic effect of calling them as retained intracorporeal foreign bodies. Such foreign bodies can be encountered in all areas of the body where surgical intervention had been previously carried out. Abdominal ${ }^{5,6}$ and thoracal cavities ${ }^{7,8}$ as well as the thigh ${ }^{6,9}$ are some locations where textilomas were reported to be encountered.

A case series of retained intracorporeal textilomas due to a previous surgery which had been followed-up or treated with documentation by two surgeons in their professional lives were presented and evaluated in the present study to describe and define the clinical and pathological characteristics in regard to data gained by a large series of textilomas during 27 years of clinical experience.

\section{MATERIAL AND METHODS}

Fourteen textiloma cases, who had been treated or whose treatment procedures had been followed-up personally by two general surgeons in a period of 27 years were retrospectively presented. Patient characteristics including gender and age, areas of location within the body, time intervals until diagnosis, clinical presentations and complaints, treatment modalities, complications, causative surgical interventions, diagnostic approaches, time until diagnosis and types of anaesthesia were recorded. Fourteen cases of retained intracorporeal textiloma were studied with a literature review in the present report.

\section{RESULTS}

Nine female and five male patients with a mean age of $43.07 \pm 15.23$ (median: 45 ) years (range 22 - 68 years) were identified in the study.

Cesarean section in three, inguinal herniorraphy in four (right inguinal hernia in one, left inguinal hernia in one, and bilateral inguinal hernia in two patients), epigastric hernia in one, explorative laparotomy because of acute abdomen in one, sigmoid colon resection in one, appendectomy and Table 1 - Presenting complaints of the patients

Patients complaints

Diffuse abdominal pain

Lower abdominal pain felt occasionally

Defecation problems with chronic colicky abdominal pain

Hyperemia with continous watery discharge changing its flow rate from time to time at the surgical wound since the causative surgical intervention (two cases with bilateral inguinal hernioraphies, one case with left inguinal hernioraphy, one case with epigastric hernioraphy, and one case with the history of thyroidectomy)

Continuing flow of serous fluid with a history of an abscess drainage

Bilateral axillary abscessses with a purulent discharge following bilateral segmental mastectomy and axillary sentinal lymph node dissection right salpingoophorectomy in one, etrangulated incisional hernia after a previous surgical intervention because of an ovarian mass in one, thyroidectomy in one and bilateral segmental mastectomy with bilateral axillary sentinal lymph node dissection because of bilateral breast carcinoma in one were the causative surgical interventions.

Locations of textilomas were the abdominal cavity in seven, inguinal surgical wound in four, abdominal surgical wound in one, thyroidectomy lodge (right side) in one, and bilateral axillary cavities in one patient.

Presenting complaints were diffuse abdominal pain in four, lower abdominal pain felt occasionally in three, defecation problems with chronic colicky abdominal pain in one, hyperemia with continous watery discharge changing its flow rate from time to time at the surgical wound since the causative surgical intervention (two cases with bilateral inguinal hernioraphies, one case with left inguinal hernioraphy, one case with epigastric hernioraphy, and one case with the history of thyroidectomy) in five (the most common complaint), continuing flow of serous fluid with a history of an abscess drainage in two and bilateral axillary abscessses with a purulent discharge following bilateral segmental mastectomy and axillary sentinal lymph node dissection findings of physical examinations in one patient (Table 1).

Data gained by physical examination were vague abdominal pain in eight (the most common clinical sign), rebound tenderness in three, palpable left inguinal mass in one, erithematous inflammation and discharge in seven, palpable abdominal mass in two, localized rigidity at the right inguinal surgical wound in one, abdominal guarding in four, abdominal distention in one and bilateral axillary rigidity with purulent discharge in one patient. None of the patients had fever which was an important finding in the study (Table 2).

Imaging techniques, which had been carried out, were abdominal computed tomography in six (Fig. 1), abdominal ultrasonography in six (Fig. 2), and bilateral axillary ultrasonography in one patient. While four of the five abdominal computed tomography images identified the retained textiloma correctly, the last case was reported as 
a pancreatic pseudocyst. Axillary, inguinal and abdominal ultrasonographic examinations succesfully mentioned about a suspect of a possible foreign body in one, two and three patients, respectively.

Air-fluid levels of small intestinal type as the only finding

Table 2 - Data gained by physical examination were detected in the direct abdominal plain x-ray of one patient because of an intraluminal surgical towel, which had penetrated the small intestinal wall insidiously without causing any damage to the bowel wall in which a complete spontaneous local cure came into existence (Fig 3).

\section{Data acquired}

Abdominal pain

Rebound tenderness

Palpable left inguinal mass

Erithematous inflammation and discharge

Palpable abdominal mass
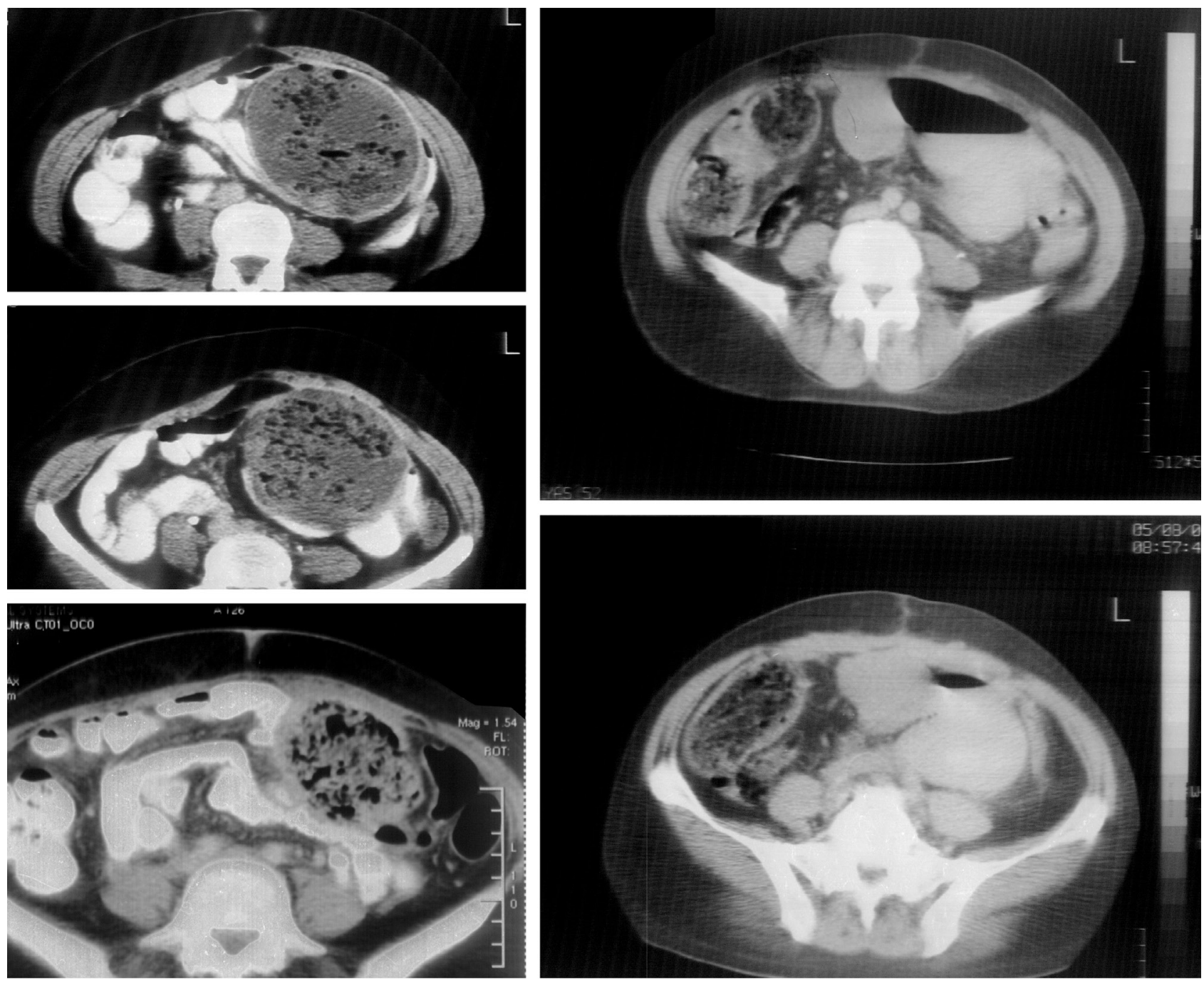

Figure 1 - Pathognomonic well demarcated characteristic mass including entrapped gaseous areas in the core and calcified cavity walls are almost a rule on computed tomography images in our series 

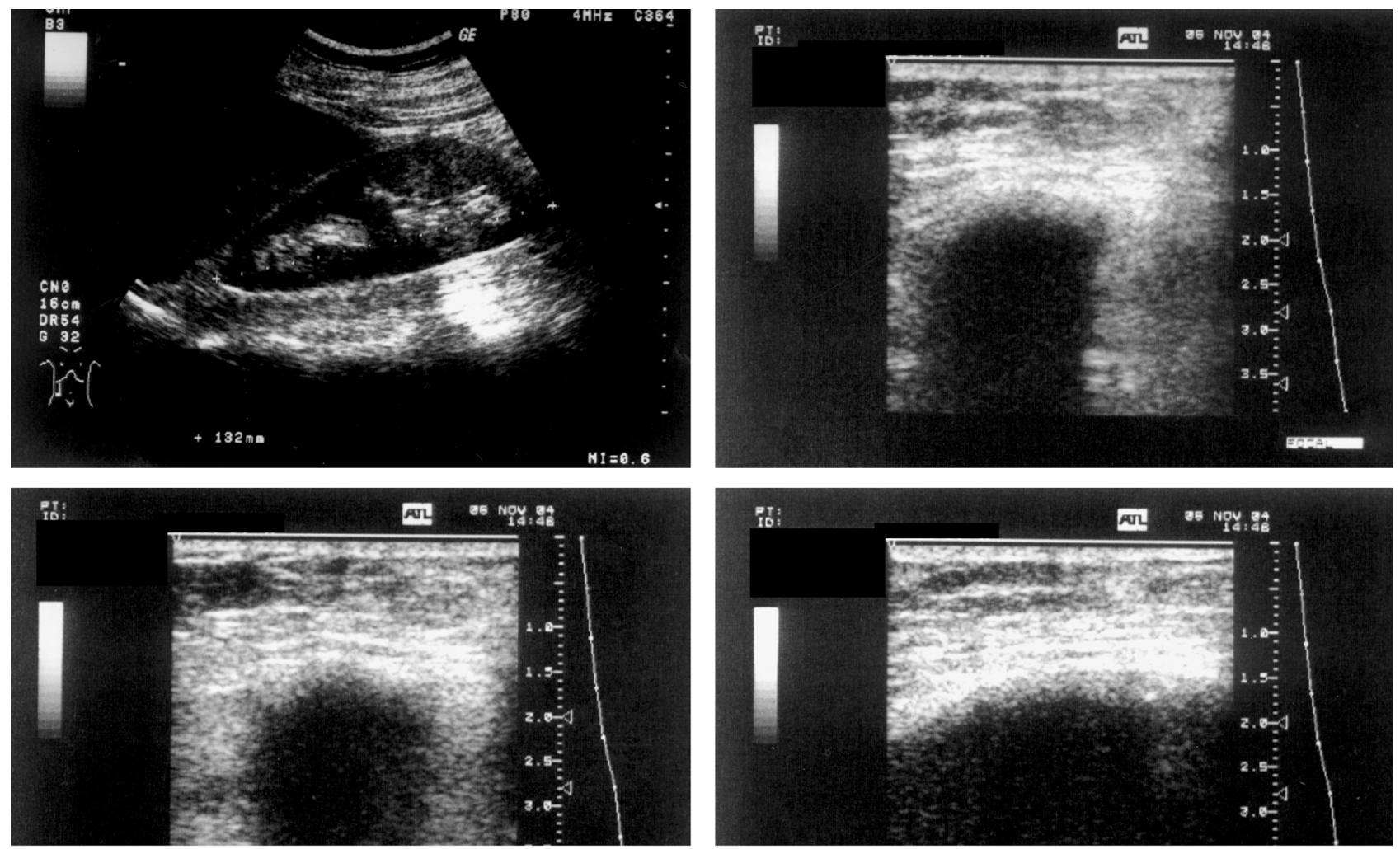

Figure 2 - Different hiperechoic whirllike structures in well demarcated cystic masses (left upper inlet image) and echogenic areas with significantly dense posterior acoustic shadowing (remaining inlet images) are detected in the ultrasonography images of our patients

All patients, except for the cases with histories of thyroidectomy and bilateral segmental mastectomy with bilateral axillary sentinal lymph node dissection, were operated on under general anaesthesia. Surgical gauzes were extirpated under local anaesthesia from the thyroidectomy lodge and bilateral axillary cavities. One or two gauzes for each patient were found in four cases with histories of inguinal hernioraphy, in one case with epigastric hernioraphy, in one case with bilateral axillary sentinal lymph node dissection because of bilateral breast carcinoma, in one case with thyroidectomy, and in one case who had undergone Cesarean section. Larger surgical towels with different sizes were the remaining retained textilomas in the latter six patients. One of the largest surgical towels which had migrated through the small intestinal wall into the intestinal lumen causing mechanical intestinal obstruction was extirpated by an enterotomy. A right hemicolectomy in one, sigmoid colectomy in one, and partial small intestinal resection in three patients were carried out because of intraabdominal adhesions caused by previous surgical interventions and textilomas, whereas one patient was treated with a colostomy because of multiple bowel perforations. A detached uterine incision wound was also repaired in one patient. There were not any postoperative complications and all patients were discharged from the hospital following an uneventful recovery period. The mean time interval until diagnosis of a retained textiloma was calculated as 14.48 (median: 5.5) months (range: 15 days - 84 months) in our presentation. Necessity of general anaesthesia in 12, additional surgery

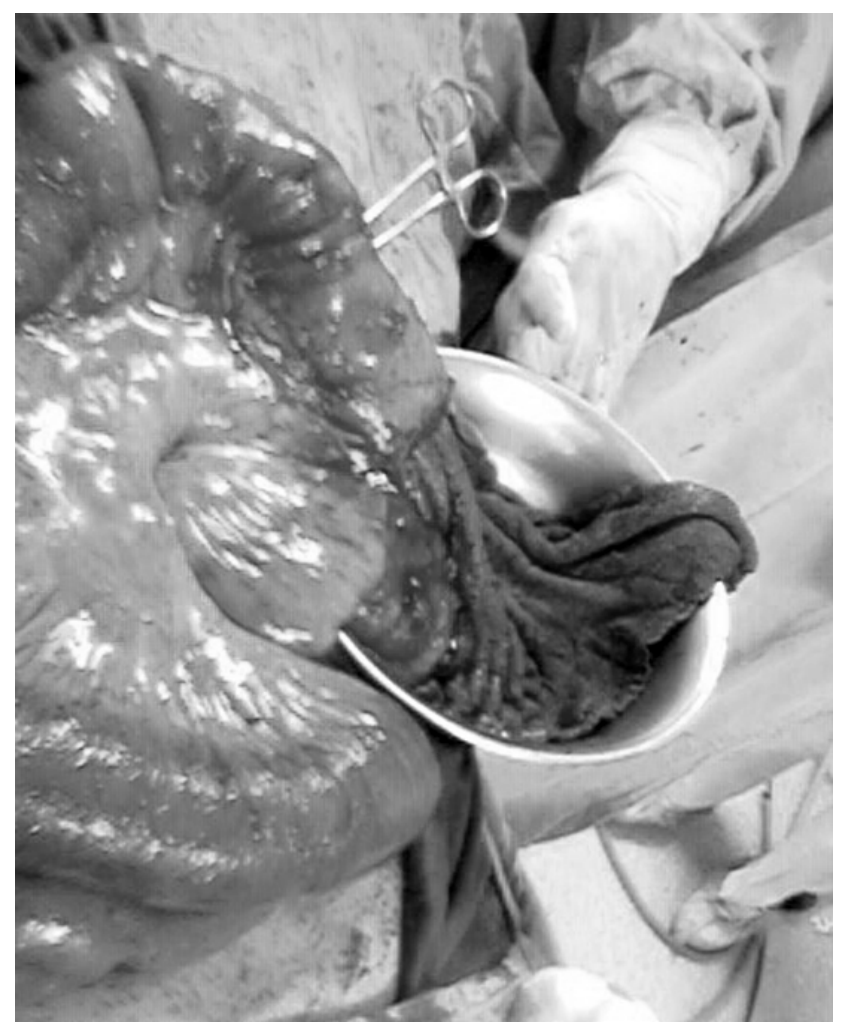

Figure 3 - Intraluminal surgical towel migrated through the small intestinal wall into the intestinal lumen (without symptomatic bowel perforation, but penetration without any anatomical sequela) causing mechanical intestinal obstruction found incidentally during laparotomy 
to take the textiloma out in 14 (all), formation of an intraabdominal abscess in four, surgical wound infection in eight, mechanical intestinal obstruction in one, necessity of a colostomy in one, and partial loss of any organ in four patients were the complications related to the retained textilomas.

\section{DISCUSSION}

The incidence of intracorporeally retained textilomas varies between $1 / 5000-1 / 100$ surgical procedures..$^{10,11}$ Gawande et $\mathrm{al}^{12}$ reported that the incidence of retained textilomas and surgical instruments had varied from 1/18 760 to $1 / 8801$ in surgical operations at non-speciality acute-care hospitals, corresponding to one case or more each year for a large hospital. It has been presumed that more than 1500 cases of foreign bodies occur annually in the USA. ${ }^{12}$ Underreporting disguises many cases even among colleagues of the same clinic especially because of medicolegal aspects according to our experience, which minimized the number of patients in our presentation despite of a long time interval of 27 years since the clues of a gossypiboma were discarded from the hospital files of some known patients with retained textilomas could not be found during the work-up of the present study. Although human faults cannot be totally eradicated, they must be reduced to a minimum.

Counting of the gauzes and surgical towels before and after the surgical intervention is a noteworthy preventive measure and it was an important defect in our cases in whom counting, even in abdominal surgical interventions, had been ignored. Moreover, most of our cases were due to minor surgical interventions where counting of surgical cottonoids were not usually recommended since they were not abdominal operations, which emphasized that gauze counting before and after the surgical intervention was more important in non abdominal surgeries than abdominal ones since the concentration of the surgical team could be loosened in minor surgeries. We think that counting of the surgical cottonoids should be generalized as a rule for all surgical interventions regardless the size of the operation. Gossypibomas can be found in all parts of the body where surgical interventions are carried out, hence they have been reported in localizations such as the abdomen, thorax, abdominal wall, extremities, urinary bladder, urethra, and neck in the literature. Our series represented a wide range of localizations such as the neck (one case), bilateral axillary cavities (one case), abdominal cavity (seven cases), and abdominal wall (five cases). These localizations gave us to think that surgical habits had been a causative factor for retained gossypibomas. Although shallow incision cavities such as the thyroid lodge, axilla and inguinal region may be interpreted as areas with low probability to forget a surgical gauze when compared to abdominal cavity, different reasons such as occupational habits of a surgeon including gauze usage as a method to control bleeding by pressure may result in a retained gauze. Especially emergent cases and bleeding conditions pay the way for retained textilomas, since cottonoids become difficult to be distinguished from surrounding structures when they absorb a high amount of blood. There are some common features of the retained textilomas. A high proportion of the cases come into being as a result of emergent surgical interventions according to many publications, where eliciting of a controlled manipulation could be more difficult to provide.5,12,13 Obesity has been interpreted as another causative factor because of the technical difficulties it induces, in addition to its pressive effect on surgeon. ${ }^{5}$ Hastiness in gauze counting, inexperienced staff, inadequate number of the staff, disorganization, emergency operation, deep seated operative locations, carelessness in gauze counting in shallow incisions, usage and pushing of a gauze intraluminally to retain intestinal materials during surgical formation of an intestinal anastomosis, physically and psychologically fatigued clinicians, total number of major procedures, multiple surgical teams, unexpected change in operative procedures, and prolonged surgical time are other factors which are blamed..$^{13} \mathrm{~A}$ usual history of surgical intervention related to obstetrics and gynecology, which is shared by many patients with retained textilomas is another noteworthy condition. ${ }^{14,15}$ However gender was not among causative factors according to a previous study like the present study. ${ }^{12}$

Intracorporeal textilomas cause two types of reactions. ${ }^{16,17}$ One of them is an aseptic fibrinous reaction where textilomas become encapsulated by a fibrous cap, which may lead to adhesive brid formation and the result is a foreign body granuloma. The second type of reaction is an exudative one ending up with an abscess with or without bacterial contamination, where the retained foreign body is tried to be expelled out of the body or is pushed into a hollow viscus by formation of a sinus tract or fistula formation. ${ }^{8,18-22}$ All described reactions and also some modified types are present in our series. Textilomas retained at the posterior bed of the stomach and abdominal cavity in two patients were totally asymptomatic except for inevident abdominal pain lasting for years. A trial to expell a surgical towel out of the body through a hollow viscus was detected in one patient, which led to mechanical intestinal obstruction (Fig. 3 ), whereas inflammatory reactions were the response of the body to expell the foreign bodies from the retained lodges in nine patients. Spontaneous transmural migration without any sequela is also possible. ${ }^{1}$

Nowadays the diagnosis of gossypibomas can easily be made by imaging techniques provided that their possibilities are reminded by the physicians. Foreign bodies with textile origin can be recognized as echogenic areas with significantly dense posterior acoustic shadowing or as different hiperechoic whirl-like structures in a well demarcated cystic mass as well as nonspesific hypoechoic or complex masses in ultrasonography, which is the most noninvasive diagnostic method. ${ }^{23-25}$ Computed tomography demontrates a well demarcated characteristic mass with thickened walls, which may harbour gaseous areas. Rim enhancement or calcifications can be obvious when 
intravenous contrast material is simultaneously given. ${ }^{17}$ On computed tomography, entrapped gas within the textiloma is visible, as are calcifications in the cavity walls especially in cases with longer durations. Internal structure of a gossypiboma can be whirl-like or spongioform due to the presence of the entrapped gas and may be low density or complex with both low density and wavy, striped or spotted high density areas on computed tomography. ${ }^{24,26}$ Magnetic reasonance imaging is another tool which could be used in its diagnosis. High or low signal intensities in T1- and T2-weighted as well as heterogenous signal intensity in T2-weighted images depending on the internal structures of the mass lesion are some characteristics of magnetic resonance imaging. ${ }^{27}$ The incapability in visualizing of a raioopaque marker in a textiloma is a disadvange of magnetic resonance imaging. The thickened wall of the capsule of a gossypiboma has low signal intensity on both T1- and T2-weighted images without remarkable gadolinium enhancement. ${ }^{28}$ According to our opinion, the usage of FDG-PET is unnecessary and a mass with hypometabolic core and hypermetabolic periphery is detected when it is used as a diagnostic procedure. ${ }^{29}$

Earlier recognition of foreign bodies can provide a better outcome. Since labeling of the surgical textile materials with radioopaque markers can prove their presence with plain X-rays demanded on purpose or unintentionally, radiopaque marking is one of the precautionary measures, which facilitates the diagnosis. Although the gauzes are labeled, this may not be helpful in diagnosis if markers are distorted by folding, twisting or disintegrated especially in cases with long duration. ${ }^{6}$ Careful counting of the gauzes and surgical towels both before and after any major or even minor surgical interventions, reexploration of the surgical site in cases of any conflict of counting, usage of the routine postoperative plain X-ray imaging to detect any incidental case if gauzes are labeled preoperatively, usage of gauzes and towels with long tails which stay extracorporeally during the operation are preventive measures to minimize the problem, although human-based errors cannot be totally abolished. A gossypiboma following its diagnosis should be taken out by an approriate intervention such as open or laparoscopic surgery as well as by endoscopy, in whom intraluminal cases are detected, in addition to different parameters of the textiloma such as its duration in the body, localization and the clinical condition it had developed. Rarely a spontaneous discharge of the foreign body by the rectal route has also been reported. ${ }^{5}$ When an intracorporeal mass is observed, surgeons should elaborately investigate the patient's past surgical history by considering the possibility of a textiloma since they can mimic any malignant condition, too. Moreover; absence of radioopaque markers in patients who underwent previous surgical interventions prior to 1980s does not exclude the possibility of textilomas since radioopaque marking of hemostatic materials came into wide use only for 30 years.

Since a period of 27 years was a very long period and a weak point of the study, it was not very reliable to add the data about the number of used pads, gauze and towels during the previous surgical interventions, however factors such as longer versus shorter operative time or intraoperative hemorrhage were really unexpectedly nonsignificant in our series.

\section{CONCLUSION}

In conclusion, textilomas are iatrogenic surgical faults which could be forgotten in different localizations intracorporeally and develop different clinical presentations causing severe hazards in patients leading to an impaired quality of life. Gossypibomas are in fact preventable burdens which create very severe problems for both patients (and surgeons) which makes their prevention far more important than their cure. Strict adherence to the rules of the operation room is a must to keep the tip of the iceberg shut in the Pandora's box.

\section{PEOPLE AND ANIMALS PROTECTION}

The authors declare that the procedures were followed according to the regulations established by the Clinical Research and Ethics Committee and to the Helsinki Declaration of the World Medical Association.

\section{CONFIDENTIALITY OF DATA}

The authors declare having followed the protocols in use at their working center regarding patient's data publication.

\section{CONFLICTS OF INTEREST}

We, as Arikan S. and Kocakusak A., certify that all our affiliations with or financial involvement in, within the past years and foreseeable future, any organization or entity with a financial interest in or financial conflict with the subject matter or materials discussed in the manuscript are completely disclosed (e.g. employment, consultancies, honoraria, stock ownership or options, expert testimony, grants or patents received or pending, royalties).

\section{FUNDING SOURCES}

No subsidies or grants contributed to this work.

\section{REFERENCES}

1. Godara R, Marwah S, Karwasra RK, Goel R, Sen J, Singh R. Spontaneous transmural migration of surgical sponges. Asian J Surg. 2006;29:44-5.

2. Manikyam SR, Gupta V, Gupta R, Gupta M. Retained surgical sponge presenting as a gastric outlet obstruction and duodeno-ileocolic fistula: report of a case. Surg Today. 2002;32:426-8.

3. Rajagopal A, Martin J. Gossypiboma "a surgical legacy": report of a

case and review of the literature. Dis Colon Rectum. 2002;45:119-20.

4. Sun HS, Cheng SL, Kuo CC, Wang SC, Kao YL. Gossypibomaretained surgical sponge. J Chin Med Assoc. 2007;70:511-3.

5. Bani-Hani KE, Gharaibeh KA, Yaghan RJ. Retained surgical sponges (gossypiboma). Asian J Surg. 2005;28:109-15.

6. Abdul-Karim FW, Benevia J, Pathria MN, Makley JT. Case report 736: retained surgical sponge (gossypiboma) with a foreign body reaction 
and remote and organizing hematoma. Skeletal Radiol. 1992;21:466-9.

7. Suwatanapongched T, Boonkasem S, Sathianpitayakul E, Leelachaikul $\mathrm{P}$. Intrathoracic gossypiboma: radiographic and $\mathrm{CT}$ findings. $\mathrm{Br} \mathrm{J}$ Radiol. 2005;78:851-3

8. Suliman HM, Blickman JG, Amrane A. Chest gossypiboma after coronary surgery. JBR-BTR. 2007;90:216-7.

9. Kominami M, Fujikawa A, Tamura T, Naoi Y, Horikawa O. Retained surgical sponge in the thigh: report of the third known case in the limb. Radiat Med. 2003;21:220-2.

10. Lauwers PR, Van Hee RH. Intraperitoneal gossypibomas: the need to count sponges. World J Surg. 2000;24:521-7.

11. Kaiser CW, Slowick T, Spurling KP, Friedman S. Retained foreign bodies. J Trauma. 1997;43:107-11.

12. Gawande AA, Studdert DM, Orav EJ, Brennan TA, Zinner MJ. Risk factors for retained instruments and sponges after surgery. $\mathrm{N}$ Engl $\mathrm{J}$ Med. 2003;348:229-35.

13. Tzeng JE, Wei CK, Chang SM, Lin CW. Surgical gauze pseudotumor (gauzoma) - a case report. Tzu Chi Med. 2006;18:49-51.

14. Apter S, Hertz M, Rubinstein ZJ, Zissin R. Gossypiboma in the early post-operative period: a diagnostic problem. Clin Radiol. 1990;42:1289.

15. Botet del Castillo FX, Lopez S, Reyes G. Diagnosis of retained abdominal gauze swabs. Br J Surg. 1995;82:227-8.

16. Olnick HM, Weens HS, Rojers JV Jr. Radiological diagnosis of retained surgical sponges. J Am Med Assoc. 1955;159:1525-7.

17. Sahin-Akyar G, Yagci C, Aytac S. Pseudotumour due to surgical sponge: gossypiboma. Australas Radiol. 1997;41:288-91.

18. Malik A, Jagmohan P. Gossypiboma: US and CT appearance. Abdominal Imaging. 2002;12:503-4.

19. Kumar S, Mavuduru R, Acharya N. Gossypiboma of the urinary bladder.
Int. J. Gynaecol Obstet. 2008;102:79-80.

20. Rafique M. Intravesical foreign bodies: review and current management strategies. Urol J. 2008;5:223-31.

21. Sharma DB, Kolte S, Bakane BC, Johrapurkar SR. Urethral migration of sponge retained at abdominal hysterectomy. Indian $\mathrm{J}$ Surg. 1997;67:150-1.

22. Erdil A, Kilciler G, Ates Y, Tuzun A, Gulsen M, Karaeren N, et al. Transgastric migration of retained intraabdominal surgical sponge: gossypiboma in the bulbus. Intern Med. 2008;47:613-5.

23. Yamato M, Ido K, Izutsu M, Narimatsu Y, Hiramatsu K. CT and ultrasound findings of surgically retained sponges and towels. J. Comput. Asist Tomogr. 1987;11:1003-6.

24. Choi BI, Kim SH, Yu ES, Chung HS, Han MC, Kim CW. Retained surgical sponge: diagnosis with CT and sonography. Am J Roentgenol. 1988;150:1047-50.

25. Sugano S, Suzuki T, linuma M, Mizugami H, Kagesawa M, Ozawa K, et al. Gossypiboma: diagnosis with ultrasonography. J Clin Ultrasound. 1993;21:289-92.

26. Kokubo T, Itai Y, Ohtomo K, Yoshikawa K, lio M, Atomi Y. Retained surgical sponges: CT and US appearance. Radiology. 1987;165:415-8.

27. Mochizuki T, Takehara Y, Ichijo K, Nishimura T, Takahashi M, Kaneko $M$. Case report: MR appearance of a retained surgical sponge. Clin Radiol. 1992;46:66-7.

28. Dux M, Ganten M, Lubienski A, Grenacher L. Retained surgical sponge with migration into the duodenum and persistent duodenal fistula. Eur Radiol. 2002;12:S74-7.

29. Yuh-Feng T, Chin-Chu W, Cheng-Tau S, Min-Tsung T. FDG PET CT features of an intraabdominal gossypiboma. Clin Nucl Med. 2005;30:561-3. 


\section{Retained Textile Foreign Bodies: Experience of 27 Years}

Acta Med Port 2015:28:494-500

Publicado pela Acta Médica Portuguesa, a Revista Científica da Ordem dos Médicos

Av. Almirante Gago Coutinho, 151

1749-084 Lisboa, Portugal.

Tel: +351218428215

E-mail: submissao@actamedicaportuguesa.com

www.actamedicaportuguesa.com

ISSN:0870-399X | e-ISSN: 1646-0758

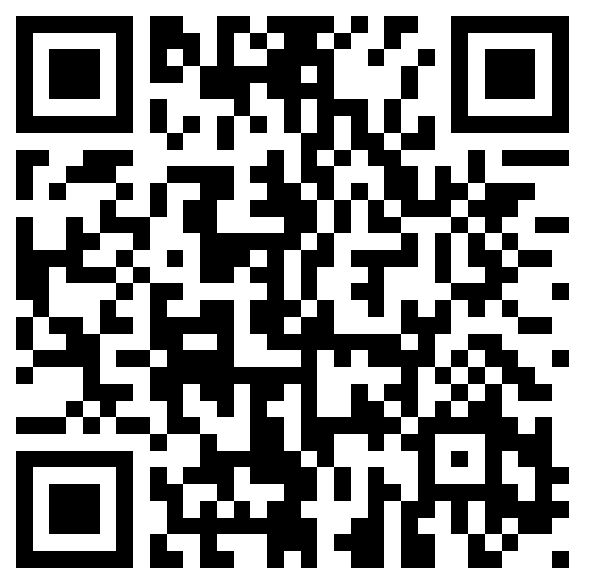

